\title{
Alkannin Inhibited Hepatic Inflammation in Diabetic Db/Db Mice
}

\author{
Wenhua Xue $\quad$ Zhirui Fann ${ }^{b, c} \quad$ Yuanzhe Lid Lifeng Lib,e Tengfei Zhang ${ }^{b, e} \quad$ Jingli Lu ${ }^{a}$ \\ Bingjun Ma ${ }^{a}$ Zijia Zhu ${ }^{a}$ Jingyao Lian ${ }^{b}$ Chaoqi Zhang ${ }^{b}$ Xiaoqin Songe \\ Dongxu Sun ${ }^{e}$ Yunkai Zhaie Ruitai Fan ${ }^{b}$ Yang Cao $^{d}$ Xiaoming Deng ${ }^{c}$ Jie Zhao ${ }^{a, e}$ \\ ${ }^{\mathrm{a}}$ Department of Pharmacy, ${ }^{\mathrm{b}} \mathrm{Cancer}$ Center, ${ }^{\mathrm{c}}$ Department of Integrated Traditional Chinese and Western \\ Medicine, the First Affiliated Hospital of Zhengzhou University, Zhengzhou, Henan, ${ }^{d}$ Department \\ of Pediatrics, the Third Affiliated Hospital of Zhengzhou University, Internet medical and system \\ applications of National engineering laboratory, Zhengzhou, China
}

\section{Key Words}

Alkannin • Liver injury $•$ Inflammation $•$ Rho-kinase pathway

\begin{abstract}
Background/Aims: The current study was designed to investigate the protective role of alkannin (ALK) on liver injury in diabetic C57BL/KsJ-db/db mice and explore its potential mechanisms. Methods: An oral glucose tolerance test (OGTT) was performed. The levels of insulin, alanine aminotransferase (ALT), aspartate aminotransaminase (AST), total cholesterol (TC) and triglyceride (TG) were determined by commercial kits. The pro-inflammatory cytokines interleukin (IL)-1 $\beta$, IL- 6 and tumour necrosis factor (TNF)- $\alpha$ were determined by ELISA. The levels of the ROCK/NF-KB pathway were determined by Western blotting. Results: The contents of pro-inflammatory cytokines interleukin (IL)- $1 \beta$, IL- 6 and tumour necrosis factor (TNF)- $\alpha$ were inhibited by ALK, metformin or fasudil in diabetic $\mathrm{db} / \mathrm{db}$ mice. Further, Western blotting analysis showed that the expression of Rho, ROCK1, ROCK2, p-NF-kBp65, and p-IкB $\alpha$ was significantly reversed by ALK treatment. In human hepatic HepG2 cells, the hepatoprotective effects of ALK were further characterized. With response to palmitic acid-challenge, increased amounts of insulin, ALT, AST, TG, and TC were observed, whereas ALK pretreatment significantly inhibited their leakage in HepG2 cells without appreciable cytotoxic effects. The inflammation condition was recovered with ALK treatment as shown by changes of IL-1 $\beta$, IL- 6 and TNF- $\alpha$. Further, Western blotting analysis also suggested that ALK improves hepatic inflammation in a Rho-kinase pathway. Conclusion: The present study successfully investigated the role of Rhokinase signalling in diabetic liver injury. ALK exhibited hepatoprotective effects in diabetic $\mathrm{db} /$ $\mathrm{db}$ mice, and it might act through improving hepatic inflammation through the Rho-kinase pathway.

W. Xue, Z. Fan and Y. Li contributed equally to this work. 


\section{Cellular Physiology Cell Physiol Biochem 2018;45:2461-2470

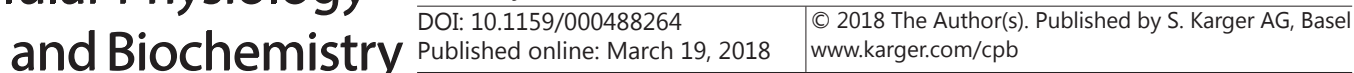 \\ Xue et al.: Alkannin Inhibits Liver Inflammation}

\section{Introduction}

Diabetes mellitus, a metabolic disease with multiple aetiologies, is characterized by chronic hyperglycaemia resulting from disturbances of insulin secretion, insulin action or both, which has been considered a major global public health challenge [1]. Approximately 382 million people were reported as living with diabetes in 2013 worldwide, and this number is estimated to reach 592 million by 2035 [2]. Diabetes mellitus causes dysregulation in carbohydrate, fat and protein metabolism, which may lead to serious complication, including blindness, renal failure, liver injury, nerve damage, and atherosclerosis $[3,4]$. Diabetes-induced liver injury has received much attention, which has been illustrated from inflammatory responses, liver fibrosis and lipid accumulation [5, 6]. Among these responses, liver inflammation is a critical mechanism, and several studies have reported that antiinflammation agents showed efficacy in reducing blood glucose level, enhanced insulin activity and protected diabetes caused by liver injury, and it may be a potential therapeutic target for this disease [7].

The Rho protein is a member of the Ras superfamily of small monomeric GTPases, which drives several of the downstream effectors proteins, including Rho-kinase. The Rhokinase pathway has been implicated in the pathological process of many diseases, including hypertension, heart failure and myocardial hypertrophy $[8,9]$. We previously found that Rho/Rho-kinase regulates the activation of NF- $\kappa B$ pathways [10]. Indeed, Rho-associated kinases converge a spectrum of pathophysiological signals triggered by the diabetic milieu and have been reported as promising molecular targets for nephroprotective treatment in diabetes [11]. To our knowledge, the role of Rho-kinase signalling in the diabetic liver injury has not previously been investigated. Natural-derived medicines are generally considered less toxic and free from side effects compared with synthetic medicines. Alkannin is an active constituent isolated from the root extract of Alkanna tinctoria, family Boraginaceae. The Boraginaceae species, including Arnebia euchroma, Lithospermium erythrorhizon and Arnebia guttata, are widely distributed plants in China. Alkannin has been used for centuries as a natural red dye and is used in Chinese popular folk medicine for its anti-inflammatory and antitumour activities [12]. Therefore, in the present study, we investigated the hepatoprotective effects of ALK underlying the diabetic liver injury by investigating Rhokinase signalling.

\section{Materials and Methods}

\section{Materials}

ALT was purchased from Jiangsu Youke Pharmaceutical Technology (Jiangsu, China). ALK was purchased from the Dalian Meilun Biotechnology Co., Ltd. (Dalian, China). Fasudil was obtained from the Tianjin Chase Sun Pharmaceutical. Co., Ltd. (Tianjin, China). Enzyme-linked immunosorbent assay (ELISA) kits for the determination of IL-1 $\beta$, IL- 6 and TNF- $\alpha$ were purchased from R\&D. All the antibodies were provided by Cell Signalling Technology (Danvers, USA).

\section{Animals}

$\mathrm{C} 57 \mathrm{BL} / \mathrm{KsJ}-\mathrm{db} / \mathrm{db}$ mice were purchased from Model Animal Research Center, Nanjing University (Nanjing, China), at 5 weeks of age and housed at $23 \pm 2{ }^{\circ} \mathrm{C}$ with a 12-h light/dark cycle. Water and food were provided ad libitum. All the experimental procedures were performed strictly according to the National Institutes of Health Guidelines for the Care and Use of Laboratory Animals and approved by China Pharmaceutical University (CPU.2012-003). After a 2-week adaptation period, the animals were divided into the following five groups: the wild-type mice group (WY), C57BL/KsJ-db/db (dbdb) mice group, C57BL/ $\mathrm{KsJ}-\mathrm{db} / \mathrm{db}$ mice + Metformin (20 mg/kg) group, C57BL/KsJ-db/db mice + ALK (20, $40 \mathrm{mg} / \mathrm{kg}$ ) group, and $\mathrm{C} 57 \mathrm{BL} / \mathrm{Ks}$ - $\mathrm{db} / \mathrm{db}$ mice + Fasudil $(5 \mathrm{mg} / \mathrm{kg})$ group. ALK and metformin were dissolved in distilled water and administered once daily for 14 weeks by gavage; simultaneously, fasudil was dissolved in normal saline and administered by gavage. Blood samples were collected from the carotid artery and centrifuged. The 


\section{Cellular Physiology Cell Physiol Biochem 2018;45:2461-2470 \\ \begin{tabular}{ll|l} 
DOI: 10.1159/000488264 & Ond Biochemistry \\
Published online: March 19, 2018 & $\begin{array}{l}\text { O 2018 The Author(s). Published by S. Karger AG, Basel } \\
\text { www.karger.com/cpb }\end{array}$ \\
\cline { 2 - 3 }
\end{tabular} \\ Xue et al.: Alkannin Inhibits Liver Inflammation}

supernatant was stored at $-80^{\circ} \mathrm{C}$ for biochemical indicators analysis. Next, the mice were sacrificed, and the livers were collected for the following analysis.

Oral glucose tolerance test

$\mathrm{C} 57 \mathrm{BL} / \mathrm{KsJ}-\mathrm{db} / \mathrm{db}$ mice were fasted overnight and orally administered with glucose at a dosage of $2 \mathrm{~g} /$ $\mathrm{kg}$ at 08:00 AM. Blood samples were obtained from the tail vein at 0, 30, 60, 90, and 120 min after glucose load. The contents of blood glucose were evaluated by using a glucose analyser (SureStep, Lifescan, Inc., Milpitas, CA).

Measurement of biomarkers in serum and cell supernatant

The levels of alanine aminotransferase (ALT), aspartate aminotransaminase (AST), total cholesterol (TC) and triglyceride (TG) in animal serum and HepG2 cell supernatant challenged with palmitic acid were determined by using commercial kits. The concentration of insulin in the serum and HepG2 cell supernatant induced by palmitic acid were measured with an insulin ELISA kit. All other chemicals used were of analytical grade.

\section{Measurement of inflammatory cytokines in serum, liver and cell supernatant}

The contents of IL-6, IL-1 $\beta$ and TNF- $\alpha$ in serum, liver tissue, and HepG 2 cell supernatant induced by palmitic acid were measured using ELISA kits from R\&D according to the manufacturer's instructions. The concentrations of these cytokines were quantified by reference to the standard curves. Next, the optical density (OD) of each well was read at $450 \mathrm{~nm}$.

\section{The Histologic examination}

The studied animals were euthanized, and the livers were carefully removed, fixed with $10 \%$ neutralbuffered formalin and embedded in paraffin. Then, the samples were sectioned into 3- $\mu$ m-thick slices and stained with haematoxylin-eosin. Immunostaining of in the liver sections was performed using a rabbit antiinsulin polyclonal antibody (Cell Signaling, Danvers, MA), followed by avidin-biotin peroxidase complex visualization (DAKO, Carpinteria, CA).

\section{Cell Culture}

HepG2 cells were cultured in Dulbecco's modified Eagle's medium (DMEM) plus 10\% foetal bovine serum and 1\% antibiotics (penicillin/streptomycin). HepG2 cells were incubated in a humidified incubator consisting of $95 \%$ air and $5 \% \mathrm{CO} 2$ at $37^{\circ} \mathrm{C}$. Three generations of HepG2 cells were passed, and then the cells were used for the experiments.

\section{Measurement of cell viability}

Cell viability was performed by MTT experiments. HepG2 cells were exposed to different concentrations of $\operatorname{ALK}(0,5,10,20,40$, and $80 \mu \mathrm{M})$ for $2 \mathrm{~h}$. Then, the HepG2 cells were exposed to $0.4 \mathrm{mM}$ of palmitic acid (Sigma-Aldrich Corp.) for $6 \mathrm{~h}$, and the cells were incubated with MTT ( $5 \mathrm{mg} / \mathrm{ml}$, Sigma) solution for $4 \mathrm{~h}$. After the interaction, $150 \mu \mathrm{l}$ of dimethyl sulphoxide (DMSO) was added, and the absorbance values were determined under a $570 \mathrm{~nm}$ wavelength by using a microplate spectrophotometer. The data were expressed as Cell viability $(\%)=($ A Treated $/ \mathrm{A}$ Control $) \times 100 \%$.

\section{Cell culture and treatment}

HepG2 cells were exposed to $\operatorname{ALK}(5,10$, and $20 \mu \mathrm{M})$ or fasudil $(10 \mu \mathrm{M})$ for $2 \mathrm{~h}$, and HepG2 cells were exposed to $0.4 \mathrm{mM}$ of palmitic acid (Sigma-Aldrich Corp.) for $6 \mathrm{~h}$, and then the cells and the cell supernatants were collected for other experiments.

\section{Western blotting}

The liver tissues and HepG2 cell cultures were homogenized, washed with PBS and lysed in a commercial RIPA buffer (Beyotime, Nanjing, China). After centrifugation at $12000 \mathrm{rpm}$ for $20 \mathrm{~min}$, the dissolved proteins were obtained from the supernatant. The protein concentrations of different groups were measured by a BCA protein assay (Beyotime, Nanjing, China). Equal amounts of protein were loaded by $10 \%$ sodium dodecyl sulphate polyacrylamide gels (SDS-PAGE) and electrotransferred onto nitrocellulose membranes. The nitrocellulose membranes were further blocked with $5 \%$ skim milk. Next, the nitrocellulose membranes were incubated with the separate antibodies against Rho (1:1 000), ROCK1 (1:1 000), ROCK2 (1:1 000), 


\section{Cellular Physiology Cell Physiol Biochem 2018;45:2461-2470

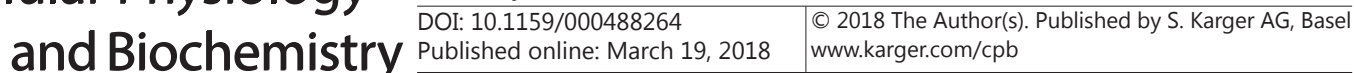 Xue et al.: Alkannin Inhibits Liver Inflammation}

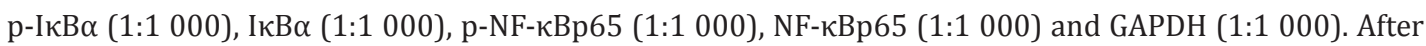
washing with TBST, the blots were incubated with horseradish peroxidase-conjugated secondary antibodies (1:10 000). The immunoreactive bands were interacted with enhanced chemiluminescence detection reagents and visualized by a gel imaging system (Tanon Science \& Technology Co., Ltd., China).

\section{Statistical Analysis}

Data are expressed as the means \pm SDs of at least three separate experiments. Statistical comparisons between the experimental groups were performed by one-way analysis of variance (ANOVA) with Tukey's multiple comparison test. A value of $\mathrm{P}<0.05$ was considered significant.

\section{Results}

\section{Effects of ALK on oral glucose tolerance test (OGTT)}

As revealed in Fig. 1, the levels of blood glucose in the C57BL/KsJ-db/db mice group were significantly increased than those in the wild-type mice group at all time points after oral administration. The C57BL/KsJ-db/ $\mathrm{db}$ mice treated with ALK $(20$ and 40 $\mathrm{mg} / \mathrm{kg}$ ) showed a significant elevation in blood glucose concentrations at $30 \mathrm{~min}$ but returned to basal levels within $2 \mathrm{~h}$ after the oral glucose administration, and similar results were also observed for C57BL/KsJ$\mathrm{db} / \mathrm{db}$ mice treated with metformin $(20 \mathrm{mg} / \mathrm{kg}$ ) or fasudil $(5 \mathrm{mg} / \mathrm{kg})$.

\section{Effects of ALK on histological examination}

Our histological examination exhibited macro vesicular steatosis in the liver tissues of the C57BL/ $\mathrm{KsJ}-\mathrm{db} / \mathrm{db}$ mice group (Fig. 2), while ALK $(20$ and $40 \mathrm{mg} / \mathrm{kg})$, metformin $(20 \mathrm{mg} / \mathrm{kg})$ or fasudil $(5 \mathrm{mg} / \mathrm{kg})$ treatment strikingly attenuated the extent of steatosis as observed in Fig. 2 . These lipid droplets were notably reduced both in size and number in the livers of C57BL/KsJ-db/db mice treated with ALK (20 and $40 \mathrm{~g} / \mathrm{kg}$ ), metformin $(20 \mathrm{mg} / \mathrm{kg})$ or fasudil (5 mg/kg), suggesting that these treatments effectively inhibit lipid accumulation in the liver and showed a significant hepatoprotective effect.

\section{Effect of ALK on Measurement of cell viability}

As shown in Fig. 3, palmitic acid inhibited HepG2 viability, and ALK (5, 10 , and $20 \mu \mathrm{M}$ ) effectively increased HepG2 viability. Fasudil $(10 \mu \mathrm{M})$ also effectively increased HepG2 viability.

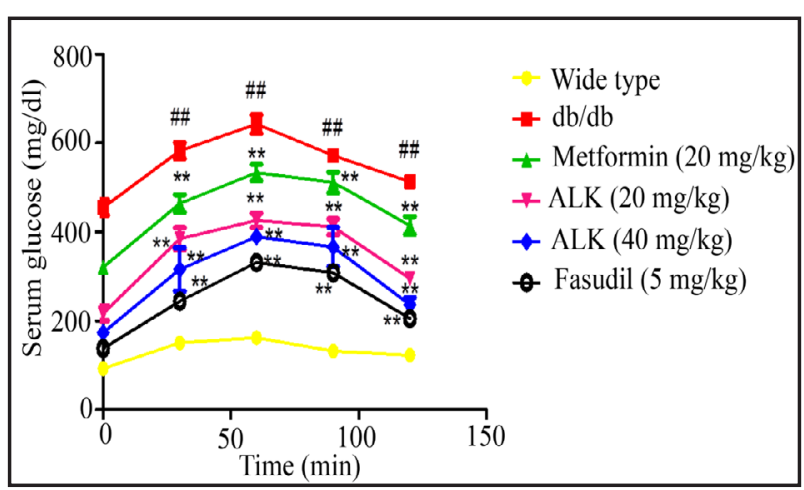

Fig. 1. Effects of ALK on oral glucose tolerance test (OGTT). $\mathrm{C} 57 \mathrm{BL} / \mathrm{KsJ}-\mathrm{db} / \mathrm{db}$ mice were fasted overnight and orally administered with glucose at a dosage of $2 \mathrm{~g} / \mathrm{kg}$ at 08:00 AM. Blood samples were obtained from the tail vein at $0,30,60$, 90 , and $120 \mathrm{~min}$ after glucose load. The data are expressed as the mean values \pm SDs. \#\#p<0.01, \#P<0.05 compared with the wild-type group. ${ }^{* *} \mathrm{p}<0.01,{ }^{*} \mathrm{P}<0.05$ compared with the dbdb group.

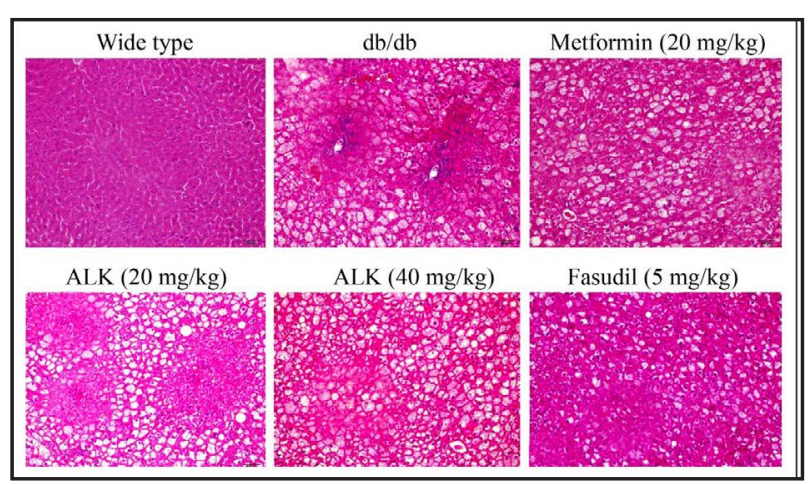

Fig. 2. Effects of ALK on histological examination (x200). The animals were euthanized, and the livers were carefully removed, fixed with $10 \%$ neutral-buffered formalin, embedded in paraffin and then stained with haematoxylineosin. 


\section{Cellular Physiology Cell Physiol Biochem 2018;45:2461-2470 \begin{tabular}{c|c|c} 
DOI: 10.1159/000488264 & and Biochemistry Published online:TMarch 19, 2018 & $\begin{array}{l}\text { O 2018 The Author(s). Published by S. Karger AG, Basel } \\
\text { www.karger.com/cpb }\end{array}$
\end{tabular}

Fig. 3. Effect of ALK on the measurement of cell viability. HepG2 cells were exposed to different concentrations of ALK $(0,5,10,20,40$, and $80 \mu \mathrm{M})$ for $2 \mathrm{~h}$. Then, the HepG2 cells were incubated with MTT ( $5 \mathrm{mg} / \mathrm{ml}$, Sigma) solution for $4 \mathrm{~h}$. After the interaction, $150 \mu \mathrm{l}$ of dimethyl sulphoxide (DMSO) was added, and the absorbance values were determined. The data are expressed as the mean values \pm SDs. \#\#p<0.01, $\mathrm{P}<0.05$ compared with the control group. ${ }^{* *} \mathrm{p}<0.01,{ }^{*} \mathrm{P}<0.05$ compared with the palmitic acid group.

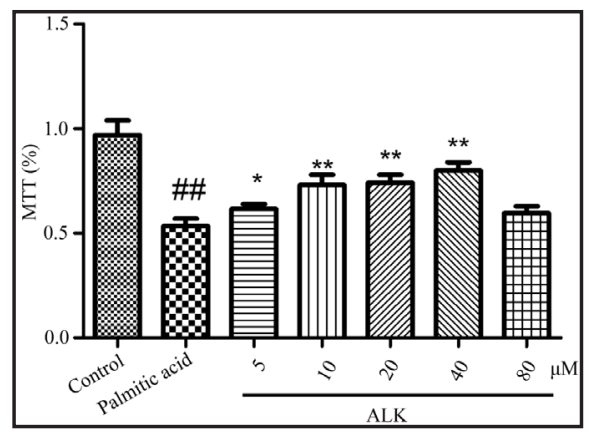

Fig. 4. Effect of ALK on biomarkers in serum (A) and cell supernatant (B). The levels of alanine aminotransferase (ALT), aspartate aminotransaminase (AST), total cholesterol (TC) and triglyceride (TG) in animal serum and HepG2 cell supernatant challenged by palmitic acid were determined with commercial kits. The data are expressed as the mean values \pm SDs. \#\#p<0.01, ${ }^{\#} \mathrm{P}<0.05$ compared with the wild-type group or control group. ${ }^{* *} \mathrm{p}<0.01, \quad * \mathrm{P}<0.05$ compared with the $\mathrm{dbdb}$ group or palmitic acid group.

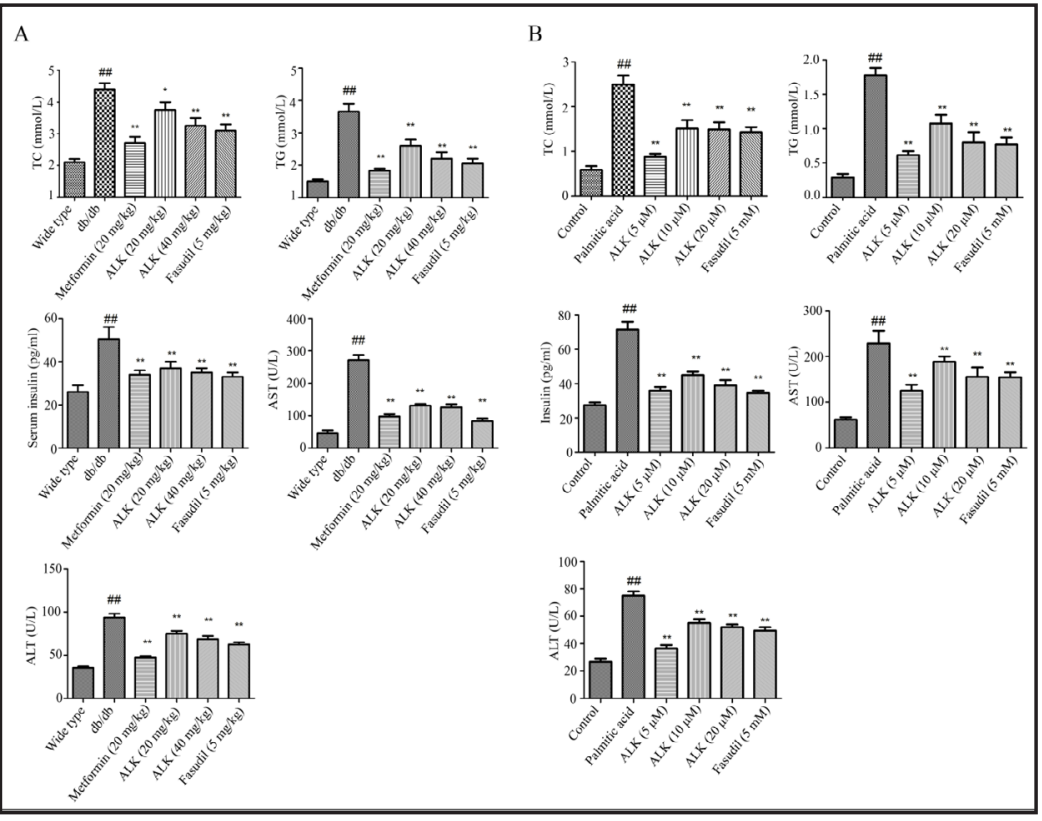

\section{Effect of ALK on biomarkers in serum and cell supernatant}

As illustrated in Fig. 4, the C57BL/KsJ-db/db mice group exhibited significantly higher serum TG and TC compared to wild-type mice. However, ALK (20 and $40 \mathrm{mg} / \mathrm{kg}$ ), metformin $(20 \mathrm{mg} / \mathrm{kg})$ or fasudil $(5 \mathrm{mg} / \mathrm{kg})$ administration led to the reversal of the abovementioned biomarkers to levels similar to those of the wild-type group. The serum levels of insulin, AST and ALT in the C57BL/KsJ-db/db mice group were significantly higher than those in the control group, and ALK (20 and $40 \mathrm{mg} / \mathrm{kg}$ ), metformin $(20 \mathrm{mg} / \mathrm{kg}$ ) or fasudil (5 mg/kg) treatment significantly reduced the serum insulin, AST and ALT compared to the model group. In HepG2 cells, in response to palmitic acid-challenge, increased amounts of insulin, ALT, AST, TG, and TC were observed, whereas ALK pretreatment significantly inhibited the leakage of these compounds from HepG2 cells (Fig. 4).

\section{Effects of ALK on inflammatory cytokines in serum and cell supernatant}

The inflammatory reaction is one of the major features in diabetic liver injury. To determine whether ALK could inhibit inflammatory responses during diabetic liver injury, serum levels of TNF- $\alpha$, IL- 6 and IL-1 $\beta$ were assessed. Significant increases in the serum levels of TNF- $\alpha$, IL- 6 and IL-1 $\beta$ were observed in the C57BL/KsJ-db/db mice group. In this regard, the serum levels of TNF- $\alpha$, IL- 6 and IL- $1 \beta$ contents were effectively decreased in the ALK $(20,40 \mathrm{mg} / \mathrm{kg})$, metformin $(20 \mathrm{mg} / \mathrm{kg})$ or fasudil $(5 \mathrm{mg} / \mathrm{kg})$ treatment groups compared with those in model mice. In palmitic acid-treated HepG 2 cells, the levels of TNF- $\alpha$, IL- 6 and 
Fig. 5. Effects of ALK on inflammatory cytokines in serum (A) and cell supernatant (B). The contents of IL-6 IL-1 $\beta$ and TNF- $\alpha$ in serum, liver tissue, and HepG2 cell supernatant induced by palmitic acid were measured using ELISA kits according to the manufacturer's instructions. The data are expressed as the mean values \pm SDs. $\# \# p<0.01, \# P<0.05$ compared with the wild-type group or control group. ${ }^{* *} \mathrm{p}<0.01,{ }^{*} \mathrm{P}<0.05$ compared with the $\mathrm{dbdb}$ group or palmitic acid group.

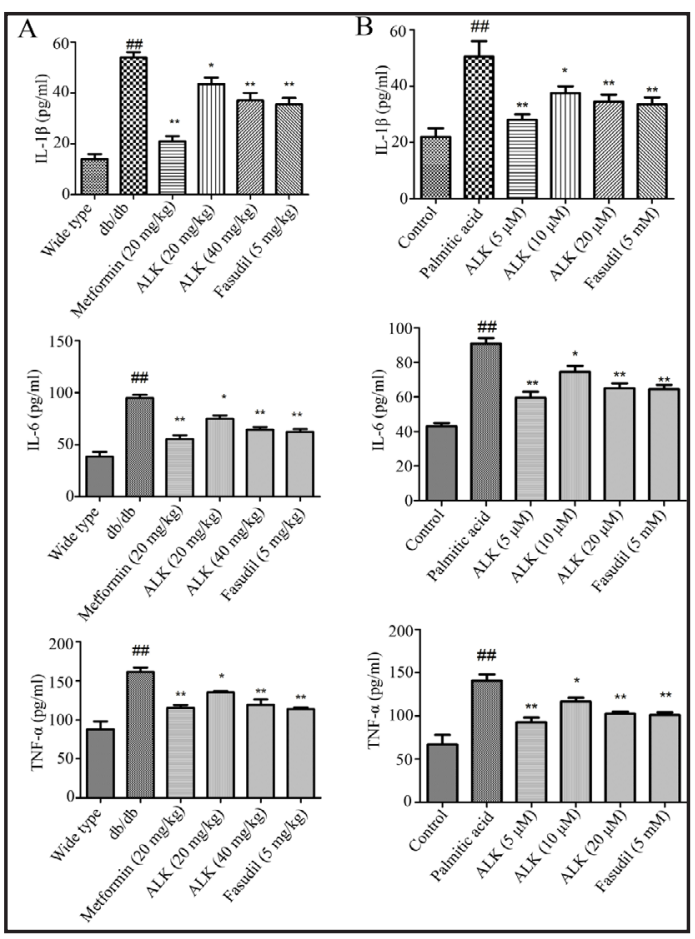

Fig. 6. Effects of ALK on the Rho Kinase pathway in mice. The levels of Rho Kinase pathway proteins in liver tissue were measured using Western blotting according to the manufacturer's instructions. A: wild type; B: dbdb; C: Metformin (20 mg/kg); D: ALK (20 mg/kg); E:ALK (40 mg/kg) F: Fasudil (5 mg/kg).

IL-1 $\beta$ were obviously increased compared with the control. The ALK and ALK + fasudil treatments led to a reversal of these inflammatory cytokines to levels similar to those of

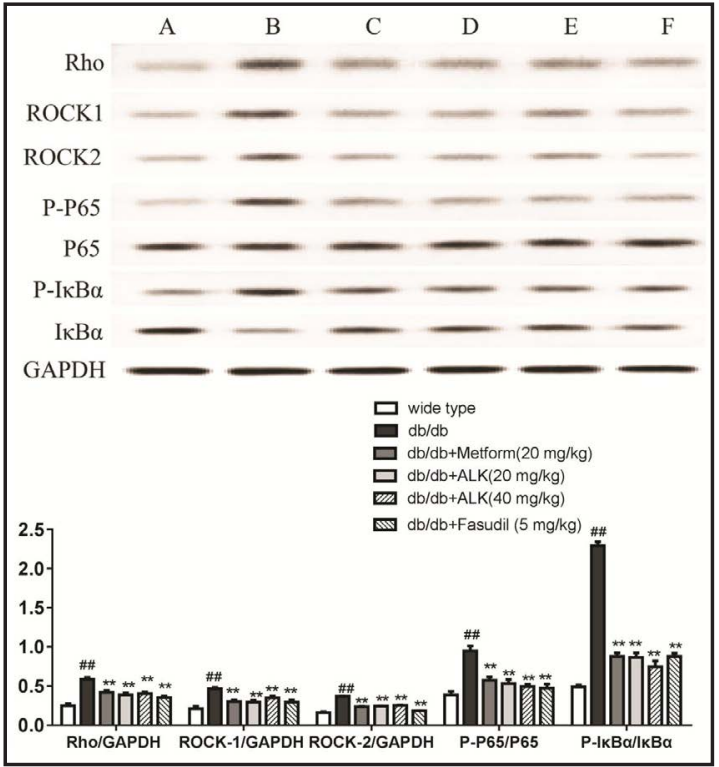
the control group (Fig. 5).

\section{Effects of ALK on Rho Kinase Pathway}

As shown in Figs. 6 and 7, the Rho kinase pathway participates in regulating the inflammatory cascades. The expression of Rho, ROCK1 and ROCK2 was significantly up-regulated in liver tissues of C57BL/KsJ-db/db mice. However, treatment with ALK (20 and $40 \mathrm{mg} /$ $\mathrm{kg})$, metformin $(20 \mathrm{mg} / \mathrm{kg})$ or fasudil $(5 \mathrm{mg} / \mathrm{kg})$ obviously ameliorated these situations. The obtained results demonstrated that ALK $(20$ and $40 \mathrm{mg} / \mathrm{kg})$ successfully blocked the expression of Rho, ROCK1 and ROCK2. To elucidate the downstream mechanism of ALK in diabetic liver injury in C57BL/KsJ-db/db mice, the phosphorylation of I $\mathrm{B}$ and NF- $\kappa \mathrm{B}$ and the expression of Ikk $\alpha$ and Ikk $\beta$ were detected. The protein levels of $p-I \kappa B$ and $p-N F-\kappa B$ were unregulated in the C57BL/KsJ-db/db mice group compared with those in the wild-type control group, while ALK (20 and $40 \mathrm{mg} / \mathrm{kg}$ ) exerted an obviously suppressive effect on diabet- 


\section{Cellular Physiology Cell Physiol Biochem 2018;45:2461-2470 \begin{tabular}{l|l} 
DOI: 10.1159/000488264 & and Biochemistry \\
Published online: March 19, 2018 & $\begin{array}{l}\text { O } 2018 \text { The Author(s). Published by S. Karger AG, Basel } \\
\text { www.karger.com/cpb }\end{array}$
\end{tabular} Xue et al.: Alkannin Inhibits Liver Inflammation}

Fig. 7. Effects of ALK on the Rho Kinase pathway in HepG2 cells. The levels of Rho Kinase pathway proteins in HepG2 were measured using Western blotting according to the manufacturer's instructions. A: Control; B: palmitic acid; C: ALK (5 $\mu \mathrm{M})$; D: ALK $(10 \mu \mathrm{M})$; E:ALK $(20 \mu \mathrm{M})$ F: Fasudil $(10$ $\mu \mathrm{M}$ ).

ic-induced phosphorylated $\mathrm{I} \kappa \mathrm{B}$ and NF- $\mathrm{KB}$. Similarly, metformin $(20 \mathrm{mg} / \mathrm{kg})$ or fasudil $(5 \mathrm{mg} / \mathrm{kg}$ ) administration was also demonstrated to have similar inhibitory effects on $\mathrm{NF}-\kappa \mathrm{B}$ signalling. These results showed that

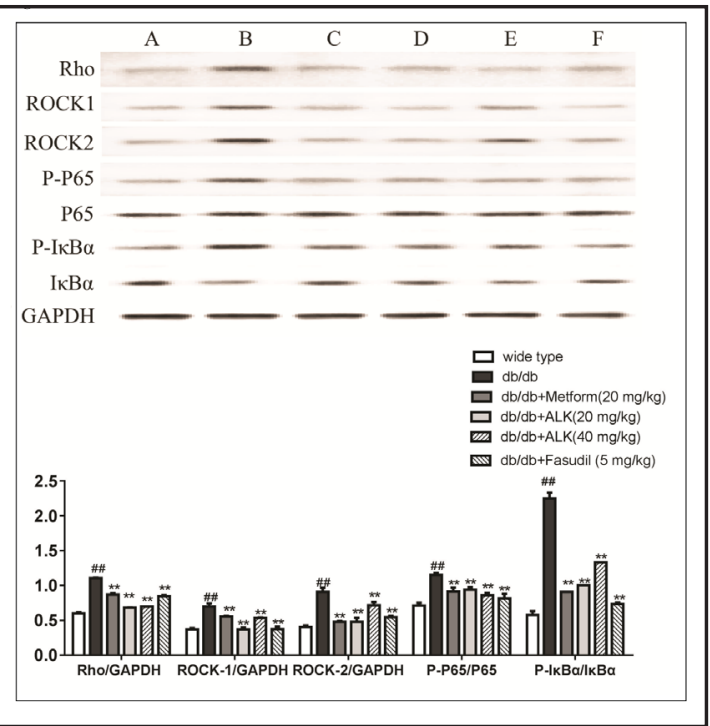
the inhibition of ROCK1 prevented the activation of NF- $\kappa \mathrm{B}$ activation. In vitro experiments showed that the expression of $\mathrm{p}-\mathrm{I} \kappa \mathrm{B}, \mathrm{p}-\mathrm{NF}-$ $\kappa B, p$-Ikk $\alpha$ and $p$-Ikk $\beta$ to $B$, and NF- $\kappa B$ were significantly increased in palmitic acid-treated HepG2 cells compared with in the control group. However, the ALK and ALK + fasudil treatment strikingly reversed these alterations (Figs. 6 and 7).

\section{Discussion}

Diabetes mellitus is characterized by hyperglycaemia, a leakage of insulin action, insulin resistance, and the progression of diabetic pathology in the retina, renal glomerulus, and nerve [13]. Diabetes also contributed to the accelerated atherosclerotic diseases affecting arteries supporting the heart, brain, and lower extremities [14]. In addition, diabetic liver injury is also a serious diabetic complication in our modern-day society. Diabetes and insulin resistance were also identified as important factors in patients with diabetic liver injury. In recent years, there has been an increasing amount of literature on diabetic complications, including metabolism of lipids. Several studies have revealed that diabetes with hyperlipidaemia may induce atherosclerosis, coronary heart disease and cerebrovascular disease. Total cholesterol (TC) and triglyceride (TG) are synthesized by the liver and are closely related to lipid metabolism. In the present study, oral glucose tolerance test performance, the level of insulin, ALT, AST, TC and TG were abnormal in diabetic C57BL/ $\mathrm{KsJ}-\mathrm{db} / \mathrm{db}$ mice.

Epidemiological studies showed that diabetic patients are at increased risk of chronic liver disease and hepatocellular carcinoma [15]. In addition, type 1 diabetes is related to higher risk of chronic liver injury, but the underlying mechanisms remain largely unknown [16]. During the development of type 2 diabetes, the insulin resistance-associated inflammation is an important mechanism associated with the pathogenesis of chronic liver disease [17, 18]. In the present study, we investigated the precise mechanism in hepatic inflammation by applying diabetic C57BL/KsJ-db/db mice, a well-established type 2 diabetic animal model, through the Rho-kinase pathway.

The elevated levels of blood glucose and insulin confirmed that the diabetic model has been well established, while the ALK treatment decreased the contents of blood glucose and insulin, indicating that ALK exerted the protective effect against diabetes. Additionally, the histopathological observation of liver sections revealed liver inflammation, whereas ALK obviously attenuated these alterations. Taken together, the present results suggested that ALK could prevent diabetes. 


\section{Cellular Physiology Cell Physiol Biochem 2018;45:2461-2470 \\ and Biochemistry Published online:March 19, $2018 \quad \begin{aligned} & \text { DOI: 10.1159/000488264 } 2018 \text { The Author(s). Published by S. Karger AG, Basel } \\ & \text { www.karger.com/cpb }\end{aligned}$ \\ Xue et al.: Alkannin Inhibits Liver Inflammation}

Inflammatory cytokines, including IL-6, IL-1 $\beta$ and TNF- $\alpha$, have been involved in the development of diabetes nephropathy. IL-1 $\beta$ is also implicated in the progression of irregularities in intraglomerular haemodynamics related to prostaglandin synthesis [19].. IL-6 increases fibronectin level, which hastens mesangial cell proliferation, disturbs extracellular matrix dynamics and increases endothelial permeability. TNF- $\alpha$ is cytotoxic to liver cells. TNF- $\alpha$ also induces direct liver damage through the generation of reactive free radicals. Moreover, several studies have described the role of ALK in inhibiting the reaction of inflammation, such as decreased the level of TNF- $\alpha$ and IL- $1 \beta$ on microglial inflammatory [20] and significantly reduced inflammation (mouse paw oedema induced by FCA) by ALK [21]. The data suggested that ALK significantly reduced the contents of inflammatory cytokines in the serum and liver tissues of diabetic mice.

Rho-kinase (ROCK), a serine/threonine protein kinase, is present in two isoforms, including ROCK1 and ROCK2. Rho-kinase is stimulated by RhoA, belonging to the Rho family of small G-proteins [19]. The Rho-kinase pathway has been implicated in the pathological process of many diseases, including hypertension, heart failure and myocardial hypertrophy $[22,23]$. Indeed, Rho-associated kinases converge a spectrum of pathophysiological signals triggered by the diabetic milieu and have been reported as promising molecular targets for nephroprotective treatment in diabetes [11]. Previous studies have suggested that the expression of Rho-kinase can be selectively blocked by its competitive inhibitors. Treatment with ROCK inhibitors improved type 2 diabetes in animal models [24]. The up-regulated Rho-kinase pathway was also reported in diabetic $\mathrm{db} / \mathrm{db}$ mice, and the ROCK inhibitor was suggested to improve the diabetic complications [25]. To our knowledge, the role of Rhokinase signalling in the diabetic liver injury has not previously been investigated. Thus, in the present study, we investigated the role of Rho-kinase signalling in diabetic liver injury by applying type 2 diabetic db/db mice. The results showed that ALK (20 and $40 \mathrm{mg} / \mathrm{kg}$ ), metformin $(20 \mathrm{mg} / \mathrm{kg})$, and fasudil $(5 \mathrm{mg} / \mathrm{kg})$ successfully blocked the expression of Rho, ROCK1 and ROCK2 and inhibited Rho kinase signalling. A similar situation was also observed in a HepG2 cell line challenged with palmitic acid.

As the downstream molecule of ROCK, NF- $\kappa B$ signalling plays a major role during the mediation of inflammatory progression in type 2 diabetes. The activation of NF- $\kappa \mathrm{B}$ is triggered by the phosphorylation and degradation of the I $\kappa \mathrm{B} \alpha$. As inhibitors of NF- $\kappa \mathrm{B}$, the

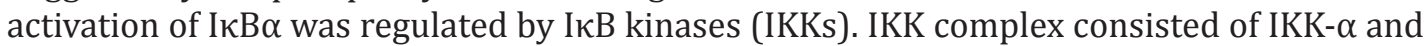
IKK- $\beta$ [26]. NF- $\kappa B$ governs the mediation of inflammatory cytokine production and affects the production of IL-1 $\beta$, IL- 6 and TNF- $\alpha$. Evidence has indicated that the Rho/ROCK/NF- $\mathrm{BB}$ pathway was involved in experimental diabetic animal models [27]. We previously found that Rho/Rho-kinase regulates the activation of NF- $\mathrm{BB}$ pathways. In the present study, ALK (20 and $40 \mathrm{mg} / \mathrm{kg})$, metformin $(20 \mathrm{mg} / \mathrm{kg})$, and fasudil $(5 \mathrm{mg} / \mathrm{kg})$ significantly inhibited the activation of Rho/ROCK/NF- $\mathrm{kB}$ signalling in C57BL/KsJ-db/db mice. Thus, the present results confirmed that ALK (20 and $40 \mathrm{mg} / \mathrm{kg}$ ), metformin $(20 \mathrm{mg} / \mathrm{kg}$ ), and fasudil $(5 \mathrm{mg} /$ $\mathrm{kg}$ ) successfully blocked the expression of ROCK and the inhibition of ROCK1 and ROCK2, which might be conducive to the suppression of NF- $\kappa \mathrm{B}$ activation.

In conclusion, the present study successfully investigated the role of Rho-kinase signalling in diabetic liver injury and characterized the potential mechanism of Rho/ROCK/NF- $\kappa \mathrm{B}$ induced inflammatory pathogenesis. ALK (20 and $40 \mathrm{mg} / \mathrm{kg}$ ) exhibited hepatoprotective effects in diabetic $\mathrm{db} / \mathrm{db}$ mice, and this chemical might act through decreasing hepatic inflammation through inhibition of the Rho-kinase pathway.

\section{Acknowledgements}

The present study was financially supported through grants from the National Natural Science Foundation of China (Grant No. 71673254, 81603122), National Key Research and Development Program of China (SQ2017YFSF090284), National Science \& Technology Huimin Program (2013GS410101), Major Program of Science \& Technology of Henan Province (121100111100), Program of Science \& Technology of Henan Province (201602037), 


\section{Cellular Physiology Cell Physiol Biochem 2018;45:2461-2470

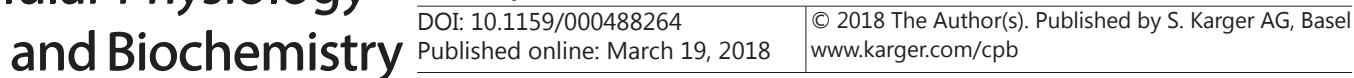 \\ Xue et al.: Alkannin Inhibits Liver Inflammation}

Innovation Scientists and Technicians Troop Construction Projects of Henan Province (144100510017), Basic and Advanced Technology Research Foundation from Science and Technology Department of Henan Province (Grant No. 122300410155), Funds for Creative Research Team of Henan Province, Creative Research Team of Higher Education of Henan Province and Innovation Team of the First Affiliated Hospital of Zhengzhou University.

\section{Disclosure Statement}

All authors have no conflicts of interest to disclose.

\section{References}

1 Ma“Kimattila S, Virkama“Ki A, Groop PH, Cockcroft J, Utriainen T, Fagerudd J, Ykija“Rvinen H: Chronic hyperglycemia impairs endothelial function and insulin sensitivity via different mechanisms in insulindependent diabetes mellitus. Circulation 1996;94:1276-1282.

2 Guariguata L, Whiting DR, Hambleton I, Beagley J, Linnenkamp U, Shaw JE: Global estimates of diabetes prevalence for 2013 and projections for 2035. Diabetes Res Clin Pract 2014;103:137-149.

3 Brownlee M: The pathobiology of diabetic complications: a unifying mechanism. Diabetes 2005;54:16151625.

4 Giacco F, Brownlee M: Oxidative stress and diabetic complications. Circ Res 2010;107:1058-1070.

5 Matafome P, Nunes E, Louro T, Amaral C, Crisostomo J, Rodrigues L, Moedas AR, Monteiro P, Cipriano A, Seica R: A role for atorvastatin and insulin combination in protecting from liver injury in a model of type 2 diabetes with hyperlipidemia. Naunyn Schmiedebergs Arch Pharmacol 2009;379:241-251.

6 Tahara A, Kurosaki E, Yokono M, Yamajuku D, Kihara R, Hayashizaki Y, Takasu T, Imamura M, Li Q, Tomiyama H, Kobayashi Y, Noda A, Sasamata M, Shibasaki M: Effects of sodium-glucose cotransporter 2 selective inhibitor ipragliflozin on hyperglycaemia, oxidative stress, inflammation and liver injury in streptozotocin-induced type 1 diabetic rats. J Pharm Pharmacol 2014;66:975-987.

7 Wellen KE, Hotamisligil GS: Inflammation, stress, diabetes. J Clinical Invest 2005;115:1111-1119.

8 Chen T, Wang R, Jiang W, Wang H, Xu A, Lu G, Ren Y, Xu Y, Song Y, Yong S, Ji H, Ma Z: Protective Effect of Astragaloside IV Against Paraquat-Induced Lung Injury in Mice by Suppressing Rho Signaling. Inflammation 2016;39:483-492.

-9 Zhu L, Chen T, Chang X, Zhou R, Luo F, Liu J, Zhang K, Wang Y, Yang Y, Long H, Liu Y, Yan T, Ma C: Salidroside ameliorates arthritis-induced brain cognition deficits by regulating Rho/ROCK/NF-kappaB pathway. Neuropharmacology 2016;103:134-142.

10 Xueyang D, Zhanqiang M, Chunhua M, Kun H: Fasudil, an inhibitor of Rho-associated coiled-coil kinase, improves cognitive impairments induced by smoke exposure. Oncotarget 2016;7:78764-78772.

11 Komers R: Rho kinase inhibition in diabetic kidney disease. Br. J. Clin. Pharmacol. 2013;76:551-559.

12 Szopa A, Ekiert R, Ekiert H: Current knowledge of Schisandra chinensis (Turcz.) Baill. (Chinese magnolia vine) as a medicinal plant species: a review on the bioactive components, pharmacological properties, analytical and biotechnological studies. Phytochem Rev 2017;16:195-218.

13 Alberti KG, Zimmet PZ: Definition, diagnosis and classification of diabetes mellitus and its complications. Part 1: diagnosis and classification of diabetes mellitus provisional report of a WHO consultation. Diabetic Med 1998;15:539-553.

14 Alexander CM, Landsman PB, Teutsch SM: Diabetes mellitus, impaired fasting glucose, atherosclerotic risk factors, and prevalence of coronary heart disease. Am J Cardiol 2000;86:897-902.

15 El-Serag HB, Tran T, Everhart JE: Diabetes increases the risk of chronic liver disease and hepatocellular carcinoma. Gastroenterology 2004;126:460-468.

16 Kim JY, Lee SH, Song EH, Park YM, Lim J-Y, Kim DJ, Choi K-H, Park SI, Gao B, Kim W-H: A critical role of STAT1 in streptozotocin-induced diabetic liver injury in mice: Controlled by ATF3. Cell Signal 2009;21:1758-1767.

17 Silva N, Harte A, Hill M, Kumar S, Day C, Mcternan P: Fatty liver disease is associated with both endotoxaemia and sub-clinical inflammation which is further aggravated by diabetes. Endocrine 2005;9:21 


\section{Cellular Physiology Cell Physiol Biochem 2018;45:2461-2470

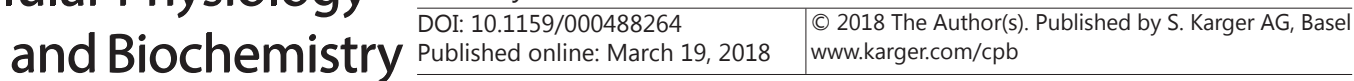 \\ Xue et al.: Alkannin Inhibits Liver Inflammation}

18 Haczeyni F, Barn V, Mridha AR, Yeh MM, Estevez E, Febbraio MA, Nolan CJ, Bellanderson KS, Teoh NC, Farrell GC: Exercise improves adipose function and inflammation and ameliorates fatty liver disease in obese diabetic mice. Obesity 2015;23:1845-1855.

19 Chen T, Guo Q, Wang H, Zhang H, Wang C, Zhang P, Meng S, Li Y, Ji H, Yan T: Effects of esculetin on lipopolysaccharide (LPS)-induced acute lung injury via regulation of RhoA/Rho Kinase/NF-small ka, CyrillicB pathways in vivo and in vitro. Free Radic Res 2015;49:1459-1468.

-20 Nam KN, Son MS, Park JH, Lee EH: Shikonins attenuate microglial inflammatory responses by inhibition of ERK, Akt, and NF-kappaB: neuroprotective implications. Neuropharmacology 2008;55:819-825.

-21 Kourounakis AP, Assimopoulou AN, Papageorgiou VP, Gavalas A, Kourounakis PN: Alkannin and shikonin: effect on free radical processes and on inflammation - a preliminary pharmacochemical investigation. Arch Pharm (Weinheim) 2002;335:262-266.

-22 Schofield AV, Bernard O: Rho-associated coiled-coil kinase (ROCK) signaling and disease. Crit Rev Biochem Mol Biol 2013;48:301-316.

23 Hartmann S, Ridley AJ, Lutz S: The Function of Rho-Associated Kinases ROCK1 and ROCK2 in the Pathogenesis of Cardiovascular Disease. Front Pharmacol 2015;6:276

24 Hollanders K, Hove IV, Sergeys J, Bergen TV, Lefevere E, Kindt N, Castermans K, Vandewalle E, Pelt JV, Moons L: AMA0428, A Potent Rock Inhibitor, Attenuates Early and Late Experimental Diabetic Retinopathy. Curr Eye Res 2016;1-13.

25 Priviero FBM, Priolli DG, Toque HAF, Nunes KP, Teixeira CE, Webb RC: Impaired Corpus Cavernosum Relaxation Is Accompanied by Increased Oxidative Stress and Up-Regulation of the Rho-Kinase Pathway in Diabetic (Db/Db) Mice. PLoS One 2016;11:e0156030.

-26 Li X, Massa PE, Hanidu A, Peet GW, Aro P, Savitt A, Mische S, Li J, Marcu KB: IKKalpha, IKKbeta, and NEMO/ IKKgamma are each required for the NF-kappa B-mediated inflammatory response program. J Biol Chem 2002;277:45129-45140.

-27 Qin XL, Bi HC, Wang XD, Li JL, Wang Y, Xue XP, Chen X, Wang CX, Xu le J, Wang YT, Huang M: Mechanistic understanding of the different effects of Wuzhi Tablet (Schisandra sphenanthera extract) on the absorption and first-pass intestinal and hepatic metabolism of Tacrolimus (FK506). Int J Pharm 2010;389:114-121. 